\title{
БИОМОРФОЛОГИЧЕСКИЕ ОСОБЕННОСТИ ФОРМИРОВАНИЯ И РЕАЛИЗАЦИИ ПОТЕНЦИАЛА ПРОДУКТИВНОСТИ У СОРТОВ КОСТОЧКОВЫХ КУЛЬТУР В УСЛОВИЯХ ЮЖНОГО САДОВОДСТВА*
}

\author{
Р.Ш. ЗАРЕМУК, Ю.А. ДОЛЯ, Т.А. КОПНИНА
}

Продуктивность плодовых культур - признак, складывающийся из комплекса элементов, который определяет устойчивость к стресс-факторам среды и востребованность сортов в промышленном производстве. У плодовых растений, в том числе у черешни и вишни, процесс дифференциации почек занимает длительный период. В условиях южного региона России (Прикубанская зона садоводства Краснодарского края) он начинается в июле текущего года и заканчивается в апреле-мае следующего. Климат в Краснодарском крае достаточно мягкий, в целом благоприятный для возделывания черешни и вишни. Вместе с тем даже на юге высок риск ежегодного воздействия на растения абиотических стрессов, из-за которых плодовые растения не могут максимально реализовать продукционный потенциал. В представленной работе на сортах черешни и вишни разного эколого-географического происхождения впервые использован метод комплексной биоморфологической оценки продуктивного потенциала. Цель исследований - выявить особенности и закономерности формирования элементов продуктивности в процессе морфо- и органогенеза у представителей Prunus subgen. Cerasus (Mill.) A. Gray, 1856, дать оценку реализации продукционного потенциала для определения наиболее уязвимых этапов в годичном цикле развития, а также выделить наиболее продуктивные сорта черешни и вишни обыкновенной для интенсивных насаждений косточковых культур в южном регионе Российской Федерации. Эксперименты проводили в 2006-2019 годах на базе опытно-производственного хозяйства «Центральное» Северо-Кавказского ФНЦ садоводства, виноградарства, виноделия (СКФНЦСВВ) (г. Краснодар). Изучали 3 интродуцированных сорта черешни Cerasus avium (L.) Moench разного эколого-географического происхождения (Валерий Чкалов, Мелитопольская черная, Полянка) и 6 сортов местной селекции (Кавказская, Сашенька, Волшебница, Дар изобилия, Алая, Мак), а также 4 интродуцированных сорта вишни обыкновенной Cerasus vulgaris Mill. (Kelleris, Nefris, Fanal, Erdi Botermo) и 7 межвидовых гибридов (черешня $\times$ вишня) - Кирина, Домбазия, Дюк Ивановна, Дюк Ходоса, Игрушка, Шалунья. Схема посадки деревьев $-6 \times 4,7 \times 3$ и $5 \times 3$ м. Подвоем служили сеянцы антипки (магалебская, или душистая, вишня) Cerasus mahaleb (L.) Mill. и дикой черешни Cerasus avium L., повторность в опыте 3-кратная. Фенологическое описание всех этапов и подэтапов годового (вегетативного и генеративного) развития растений проводили по международной кодирующей системе ВВСН (Biologische Bundesanstalt, Bundessortenamt and Chemische Industrie, Германия). Для микроскопического исследования морфогенеза плодовых образований отбирали по 15 генеративных почек 2 раза в декабре и феврале, еженедельно - в марте-апреле и июле-ноябре. В весенний период на скелетных ветвях 3-го порядка вели поэтапный подсчет сформировавшихся цветков, завязей, плодов и оценивали степень их редукции. Учет числа плодовых и ростовых почек проводили 2 раза в неделю в августе и сентябре. Для изучения зимостойкости брали по 90 вегетативных и 180 плодовых почек с трех деревьев одного сорта, с разных сторон нижних и верхних ветвей в 3-кратной повторности. Было установлено, что редукция элементов продуктивности в условиях южного садоводства происходит на одних и тех же (критических) этапах развития плодового растения. Мы выделили пять таких критических этапов с более высокой вероятностью редукции элементов: закладка генеративных органов, формирование археспория в пыльниках, образование материнских клеток пылыцы, стадия однодвухъядерной пыльцы и макроспорогенез. В условиях Краснодарского края уточнены средние сроки прохождения критических этапов формирования компонентов продуктивности - II-III декады марта, I-II декады апреля, мая и июля. Обнаружена прямая корреляционная зависимость $(r=+0,97$, p $<0,001)$ между числом элементов плодоношения, сохранившихся после редукции, и стрессовыми температурами на всех уязвимых этапах органогенеза. В результате выявлены отечественные сорта черешни с высоким коэффициентом плодоношения и урожайностью - Кавказская (соответственно $62 \%$ и 31,3 т/га), Алая (46\% и 30,0 т/га), Сашенька (45\% и 26,6 т/га), Волшебница (42\% и 23,3 т/га), а также вишне-черешневые гибриды Дюк Ходоса (46\% и 23,3 т/га), Кирина (44\% и 23,3 т/га), Дюк Ивановна (44\% и 20 т/га) и сорт вишни обыкновенной Kelleris (45\% и 20 т/га). Указанные сорта рекомендуются для возделывания в условиях южного садоводства, а также для использования в селекционных программах в качестве источников генов устойчивости к температурным стрессам и высокой продуктивности.

\footnotetext{
* При выполнении исследований использовано оборудование Центра коллективного пользования (ЦКП)
} «Генетическая коллекция плодовых культур» ФГБНУ СКФНЦСВВ (г. Краснодар). 
Ключевые слова: плодовые культуры, косточковые, черешня, вишня обыкновенная, органогенез, морфогенез, генеративное развитие, элементы продуктивности, сорт, адаптивность, урожайность.

Погодные стрессы, вызванные происходящими в настоящее время глобальными климатическими изменениями, негативно влияют на продуктивность сельскохозяйственных растений, в том числе плодовых косточковых (в частности, представителей рода Prunus L.) $(1,2)$. По прогнозам ученых, в перспективе вероятно повышение средней температуры воздуха на $1,5-2,7{ }^{\circ} \mathrm{C}(1,3)$, что может привести к сдвигу годичного ритма развития и нарушению продукционного процесса у плодовых культур (4). Очевидно, что при воздействии стрессовых факторов сорта не смогут максимально реализовывать потенциал продуктивности (5). Это требует более глубокого изучения процессов формирования генеративных органов для разработки превентивных мер по сохранению будущего урожая на критических, наиболее уязвимых этапах онтогенеза плодовых растений.

Краснодарский край - один из южных регионов России с достаточно благоприятными для возделывания плодовых растений погодноклиматическими условиями (6). Вместе с тем даже на юге высок риск ежегодных абиотических стрессов (7). Прежде всего, это морозы в период покоя, возвратные весенние заморозки, осадки, туман, суховеи и высокие температуры в период цветения, вызывающие повреждения репродуктивных органов, снижение урожая, а в некоторые годы - его гибель $(8,9)$. По мнению ряда ученых, доля влияния погодных условий на продуктивность плодовых культур составляет около 50 \% (10), биологических особенностей сорта $-40 \%$ (11), антропогенных факторов - $10 \%(7,12)$. В других источниках приводятся данные о более высокой доле влияния сортовой специфики на продуктивность косточковых $(6,8)$.

Известно, что формированию урожая плодового растения предшествует длительный период, включающий закладку и дифференциацию плодовых почек - последовательные этапы в годичном цикле развития. На каждом этапе осуществляются процессы, обусловливающие продуктивность культуры и сорта $(10,13)$. У плодовых растений, в том числе у черешни и вишни, дифференциация почек занимает длительный период $(5,14)$. В условиях южного региона России (Прикубанская зона садоводства Краснодарского края) он начинается в июле текущего года и заканчивается в апреле-мае следующего (5). Так, у яблони дифференциация длится в среднем 140-150 сут $(10,12)$, у черешни - 117-130 сут (6). К началу периода покоя (декабрь) у плодовых почек черешни и вишни формируются зачатки органов цветка - пестики и тычинки (15), что делает их менее морозостойкими и более уязвимыми (8). В это же время у растений яблони плодовые почки менее дифференцированы, что обусловливает их большую зимостойкость $(12,16)$.

Установлено, что морозы от $-26,0$ до $-28,0{ }^{\circ} \mathrm{C}$ в период покоя ведут к значительному подмерзанию или гибели плодовых почек у черешни (17), а температура от $-29,0$ до $-30,0{ }^{\circ} \mathrm{C}$ вызывает подмерзание или гибель плодовых образований у вишни (14). Приводятся данные, что раскрытые цветки черешни и вишни гибнут при температуре от $-2,0$ до $-2,2{ }^{\circ} \mathrm{C}$, закрытые бутоны - от $-2,4$ до от $-5,0{ }^{\circ} \mathrm{C}(17)$, а пестики цветков особенно чувствительны к весенним заморозкам $(9,18)$. Доказано, что недостаток суммы низких отрицательных температур в период покоя ведет к раннему выходу некоторых косточковых культур (абрикос, алыча, слива русская, черешня) из вынужденного покоя (19). Из-за этой биологической особенности возрастает степень воздействия морозов на генеративные органы 
растений $(20,21)$, в результате чего нарушается синхронность в развитии органов цветка $(22,23)$ с дисфункцией мужской генеративной сферы, то есть снижается жизнеспособность и качество пыльцы, а также нарушается процесс оплодотворения $(21,24)$.

Негативное влияние на формирование генеративной сферы плодовых растений оказывает также высокотемпературный стресс (25). Установлено, что для дифференциации плодовых почек яблони оптимальна температура 23,0-30,0 ${ }^{\circ} \mathrm{C}$ (26) и что при температуре выше $30,0{ }^{\circ} \mathrm{C}$ этот процесс приостанавливается (27). Считается, что созревание пыльцы черешни и вишни начинается при $22-23,0{ }^{\circ} \mathrm{C}(24,28)$, а для семяпочки алычи температура $25,0{ }^{\circ} \mathrm{C}$ губительна (29). По результатам некоторым исследований, экстремально высокие температуры обусловливают сокращение периода эффективного опыления (30), при закладке цветковых почек в таких условиях под угрозой находится механизм морфогенеза, а значит, и будущий урожай $(31,32)$.

Таким образом, очевидно, что в условиях температурных стрессов плодовые растения не могут максимально реализовать продукционный потенциал, поскольку генерируют физиологический стрессовый ответ, позволяющий клеткам выжить (33). Исследования закономерностей формирования элементов урожайности, а также реализации потенциала продуктивности у плодовых культур в условиях температурных стрессов носят разрозненный характер и остаются недостаточно полными, что и определило необходимость проведенных нами исследований.

В представленной работе в условиях Краснодарского края на сортах черешни и вишни разного эколого-географического происхождения нами впервые использован метод комплексной биоморфологической оценки продуктивного потенциала. Выявлены пять критических этапов органогенеза и средние сроки их прохождения в условиях воздействия стрессовых факторов. Установлена тесная зависимость реализации продуктивного потенциала растений от типов температурного стресса в эти периоды и сохранности элементов плодоношения после редукции.

Цель исследований - выявить особенности и закономерности формирования элементов продуктивности в процессе морфо- и органогенеза у представителей рода Prunus L., дать оценку реализации продукционного потенциала для определения наиболее уязвимых этапов в годичном цикле развития, а также выделить наиболее продуктивные сорта черешни и вишни обыкновенной для интенсивных насаждений косточковых культур в южном регионе Российской Федерации.

Методика. Исследования проводили в Прикубанской зоне садоводства Краснодарского края в 2006-2019 годах на базе опытно-производственного хозяйства «Центральное» Северо-Кавказского ФНЦ садоводства, виноградарства, виноделия (СКФНЦСВВ) (г. Краснодар).

Объектами изучения были 3 интродуцированных сорта черешни Cerasus avium (L.) Moench разного эколого-географического происхождения (Валерий Чкалов, Мелитопольская черная, Полянка) (Украина), 6 сортов отечественной селекции (Кавказская, Сашенька, Волшебница, Дар изобилия, Алая, Мак) (Россия), 4 интродуцированных сорта вишни обыкновенной Cerasus vulgaris Mill. - Kelleris (Дания), Nefris (Польша), Fanal (Германия), Erdi Botermo (Венгрия) и 7 межвидовых гибридов (черешня $\times$ вишня) - Кирина (Россия), Домбазия (Средняя Азия), Дюк Ивановна (Украина), Дюк Ходоса (Украина), Игрушка (Украина), Шалунья (Украина). Агротехника на опытном участке - общепринятая для региона. Схема посадки деревьев $-6 \times 4,7 \times 3$ и $5 \times 3$ м. Подвоем служили сеянцы антипки 
(магалебская, или душистая, вишня) Cerasus mahaleb (L.) Mill. и дикой черешни Cerasiis avium L., один сорт - один вариант (по методике сортоизучения), повторность в опыте 3-кратная.

Фенологическое описание всех этапов и подэтапов годового (вегетативного и генеративного) развития растений проводили по международной кодирующей системе ВВСН (Biologische Bundesanstalt, Bundessortenamt and Chemische Industrie, Германия) (34). Биологическую урожайность сортов и степень повреждения плодовых почек морозами оценивали по соответствующим методикам $(35,36)$. Регистрировали фенофазы (фотоаппарат Canon EF-S, Япония) и этапы органогенеза (световая микроскопия, Olympus BX41, «Olympus Corporation», Япония).

В весенний период на скелетных ветвях 3-го порядка вели поэтапный подсчет сформировавшихся цветков, завязей, плодов и оценивали степень их редукции. Число плодовых и ростовых почек подсчитывали в августе и сентябре 2 раза в неделю (5).

Для микроскопического исследования морфогенеза плодовых образований отбирали по 15 генеративных почек 2 раза в декабре и феврале, в марте-апреле и июле-ноябре - еженедельно.

Временные анатомические препараты готовили следующим образом: лезвием бритвы проводили от основания плодовой почки к ее верхушке, поперечные срезы фиксировали в дистиллированной воде и просматривали на предметном стекле под микроскопом при увеличении $\times 50-100$. Пыльники с помощью иглы доставали из плодовой почки, предварительно окрашивая ацетокармином на предметном столе микроскопа, придавливали покровным стеклом и просматривали при увеличении $\times 100-200$ (микроскоп Olympus BX41). Описание этапов и подэтапов органогенеза и микроспорогенеза проводили по классической методике И.С. Исаевой (37), приготовление анатомических препаратов плодовых почек для микроскопирования осуществляли по усовершенствованной методике Г.К. Киселевой (38).

Элементы плодоношения (на букетных веточках и однолетних побегах с формирующимися на них плодовыми почками) учитывали в августе-сентябре на скелетных ветвях 3-го порядка (1-2 типичные ветви на южной и восточной стороне дерева) на трех деревьях каждого сорта в 3кратной повторности. Коэффициент плодоношения (Кп) сортов рассчитывали по формуле: Кп = число плодов/число цветков $\times 100 \%$ (все цветки, сформировавшиеся на 1 м плодовой древесины, принимали за $100 \%$ ).

Для изучения зимостойкости брали по 90 вегетативных и 180 плодовых почек с трех деревьев одного сорта, с разных сторон нижних и верхних ветвей в 3-кратной повторности.

В стандартном пакете программ Microsoft Excel 2013 вычисляли средние арифметические $(M)$, стандартные отклонения $( \pm \mathrm{SD})$ и $\mathrm{HCP}_{05}$ с достоверной вероятностью $95 \%$. Коэффициент вариации $(C v, \%)$ и относительную стандартную ошибку выборочной средней (ошибка выборки) $(\mathrm{Sx}=\mathrm{SD} / \sqrt{M}, \%)$ рассчитывали по стандартной методике (35). Корреляционный анализ показателей повреждения плодовых почек в зависимости от сорта и условий года исследования выполняли при помощи пакета Statistica («StatSoft, Inc.», США) (2019).

Результаты. Климат в Прикубанской зоне Краснодарского края достаточно мягкий, в целом благоприятный для возделывания черешни и вишни. Среднегодовая температура воздуха зоны составляет $11,9-12,1{ }^{\circ} \mathrm{C}$. Максимальные температуры в июле-августе достигают 40,0-40,7 ${ }^{\circ} \mathrm{C}$, минимальные в январе-феврале могут опускаться до $-33,0{ }^{\circ} \mathrm{C}$. 
1. Редукция элементов плодоношения (плодовых почек, цветков, завязей) на критических этапах формирования продуктивности у изученных сортов черешни Cerasus avium (L.) Moench и вишни обыкновенной Cerasus vulgaris Mill. при воздействии погодных стрессов (ОПХ «Центральное» СКФНЦСВВ, г. Краснодар, 2006-2019 годы)

\begin{tabular}{|c|c|c|c|c|}
\hline \multirow{2}{*}{ Фенофаза (этап по ВВСН) } & \multirow{2}{*}{$\begin{array}{l}\text { Этап органогенеза и } \\
\text { микроспорогенеза (период) }\end{array}$} & \multicolumn{2}{|c|}{ Температура, влажность воздуха в период прохождения фенологической фазы } & \multirow{2}{*}{ Редукция, \% } \\
\hline & & оптимальные условия & неблагоприятные условия & \\
\hline $\begin{array}{l}\text { Начало формирования орга- } \\
\text { нов цветка в плодовых почках } \\
\text { Период покоя (00) }\end{array}$ & $\begin{array}{l}\text { IV - формирование генеративных } \\
\text { органов (I-II декады июля) } \\
\text { VI - археспориальная ткань }\end{array}$ & Не выше $30-33{ }^{\circ} \mathrm{C}$ при влажности 40-47 \% & Выше $35-37^{\circ} \mathrm{C}$ при влажности менее $40 \%$ & $20-30$ \\
\hline & в пыль & Выше $-24{ }^{\circ} \mathrm{C}$ при влажности $65-75 \%$ & Ниже $-28^{\circ} \mathrm{C}$ при влажности $75-80 \%$ & $85-100$ \\
\hline Раздвижение чешуй (51) & $\begin{array}{l}\text { VII - материнские клетки } \\
\text { пыльцы (II-III декады марта) }\end{array}$ & Не ниже 9-10 ${ }^{\circ} \mathrm{C}$ при влажности $60 \%$ & Ниже $-10^{\circ} \mathrm{C}$ при влажности $65 \%$ & $15-70$ \\
\hline $\begin{array}{l}\text { Цветение-белый бутон (60- } \\
65 \text { ) } \\
\text { Формирование завязи (71-72) }\end{array}$ & $\begin{array}{l}\text { IX - одно-двухъядерная пыльца } \\
\text { (I-II декады апреля) } \\
\text { X - макроспорогенез }\end{array}$ & В пределах $16-25{ }^{\circ} \mathrm{C}$ при влажности $55-58 \%$ & От $-3,0$ до $-6,0^{\circ} \mathrm{C}$; ниже $16^{\circ} \mathrm{C}$ при влажности $60 \%$ & 20-95 \\
\hline$+\frac{1}{2}$ & (I-II декады мая) & В пределах $25,0-28,0^{\circ} \mathrm{C}$ при влажности $54-60 \%$ & Выше $28,0-30,0{ }^{\circ} \mathrm{C}$ при влажности $75 \%$ & $40-46$ \\
\hline
\end{tabular}


Анализ погодных условий в годы исследований подтвердил их динамичность и свидетельствовал о комплексе стабильно повторяющихся температурных стрессов. Так, в январе 2006 года в регионе отмечались аномально низкие температуры (от $-32,0{ }^{\circ} \mathrm{C}$ до $-33,0{ }^{\circ} \mathrm{C}$, которые привели к гибели всех плодовых культур (17). В феврале 2014 года при отрицательных температурах $\left(-22,2{ }^{\circ} \mathrm{C}\right)$ имел место ледяной дождь, приведший к гибели урожая всех плодовых растений. В январе 2015 года и декабре 2016 года в период покоя после того, как долгое время сохранялась теплая погода, температура воздуха опустилась соответственно до $-21{ }^{\circ} \mathrm{C}$ и $-17,0{ }^{\circ} \mathrm{C}$, что привело к подмерзанию плодовых почек у черешни. За срок наблюдений практически раз в 2 года (2009, 2010, 2014, 2015, 2018 годы) в июле-августе (на эти месяцы приходится закладка и дифференциация плодовых образований) отмечали аномально высокие температуры $(38,0$ $\left.40,0{ }^{\circ} \mathrm{C}\right)$, сопровождавшиеся периодами засухи длительностью 4-5 сут и более. Во время цветения растений черешни и вишни ежегодно имели место возвратные весенние заморозки (от $-3,0$ до $-6,0^{\circ} \mathrm{C}$ ), приводившие к подмерзанию и гибели тычинок и рыльца пестиков, а при температуре ниже $16{ }^{\circ} \mathrm{C}$ и влажности воздуха $60 \%$ нарушался процесс оплодотворения (табл. 1).

В этих условиях из 12 изученных этапов морфогенеза у сортов черешни и вишни обыкновенной было выделено 5 наиболее уязвимых, то есть с высокой степенью редукции элементов продуктивности. Мы также определили оптимальные и экстремальные условия для каждой фенофазы (этапа органогенеза) (табл. 1). Аналогичные исследования по яблоне позволили выявить только 4 критических этапа (37).
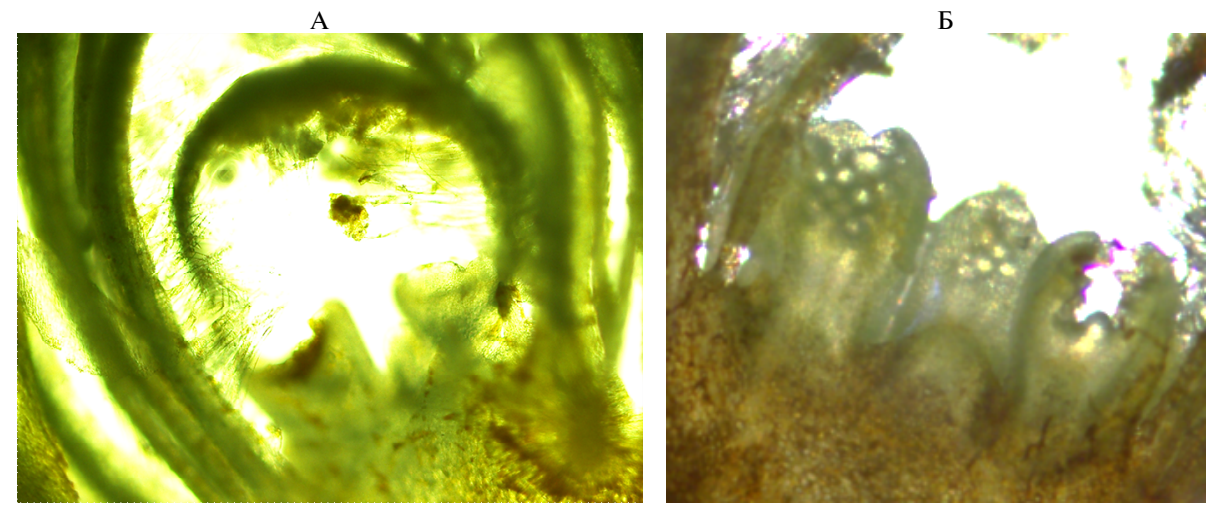

Рис. 1. Формирование генеративных органов (появление и рост генеративного бугорка) у черешни Cerasus avium (L.) Moench сорта Алая на IV этапе органогенеза (A, 23 июля 2017 года, неблагоприятные условия - температура выше 35-37 ${ }^{\circ} \mathrm{C}$, влажность воздуха менее $40 \%$ ) и появление бугорков пестиков у вишни Cerasus vulgaris Mill. сорта Кирина на V этапе органогенеза (Б, 10 ноября 2018 года, условия, близкие к оптимальным - температура выше $-6,5{ }^{\circ} \mathrm{C}$, влажность воздуха 65-75 \%) в Прикубанской зоне садоводства Краснодарского края (увеличение $\times 50-100$, Olympus BX41, «Olympus Corporation», Япония). Описание происхождения сортов см. в разделе «Методика».

Сравнительный анализ состояния цветковых почек у разных сортов черешни и вишни в I-II декадах июля (IV этап органогенеза) позволил установить, что при неблагоприятных температурных условиях формировалось всего 1-2 цветочных зачатка вместо 3-5 (см. табл. 1, рис. 1, А), а при близких к оптимальным - все органы цветка и археспориальная ткань в пыльниках (3 меристематических бугорка и более) (см. табл. 1, рис. 1, Б), которые редуцировались в зачатки будущих цветков. На IV этапе органогенеза при неблагоприятных температурных условиях редукция 
органов цветка составляла в среднем 20-30\%.

По данным ряда исследователей, плодовые почки имеют наибольшую зимостойкость на стадии первичного археспория, соответствующей VI этапу $(15,29)$, который мы отмечали в декабре-январе (рис. 2). Этот этап органогенеза мы рассматриваем как второй критический (см. табл. 1), на котором в условиях Краснодарского края высока вероятность воздействия морозов и гибель плодовых почек. Так, в 2006 году - самом аномальном за последние десятилетия снижение температуры воздуха до $-33,0{ }^{\circ} \mathrm{C}$ в период покоя привело к 100 \% гибели цветочных почек у большинства сортов черешни и вишни. Была выявлена тесная корреляционная зависимость $(r=+0,991, \mathrm{p}<0,001)$ между воздействием критической температуры и гибелью плодовых почек. В частности, 100 \% гибель генеративных органов отмечали у интродуцированных сортов черешни Полянка и Валерий Чкалов. У сортов местной селекции Алая, Волшебница и Дар изобилия гибель плодовых почек составила 90 \% и сформировался урожай 5,0-5,5 кг/дерево, что свидетельствует о морозоустойчивости этих сортов. Высокую устойчивость к морозам имели также межвидовые гибриды (гибель почек - 90-95\%, урожай плодов - 4,0-6,0 кг/дерево). У изученных сортов вишни обыкновенной гибель почек была ниже и составила в среднем 85-90 \%, при этом сформировался урожай 5,0-8,0 кг/дерево.
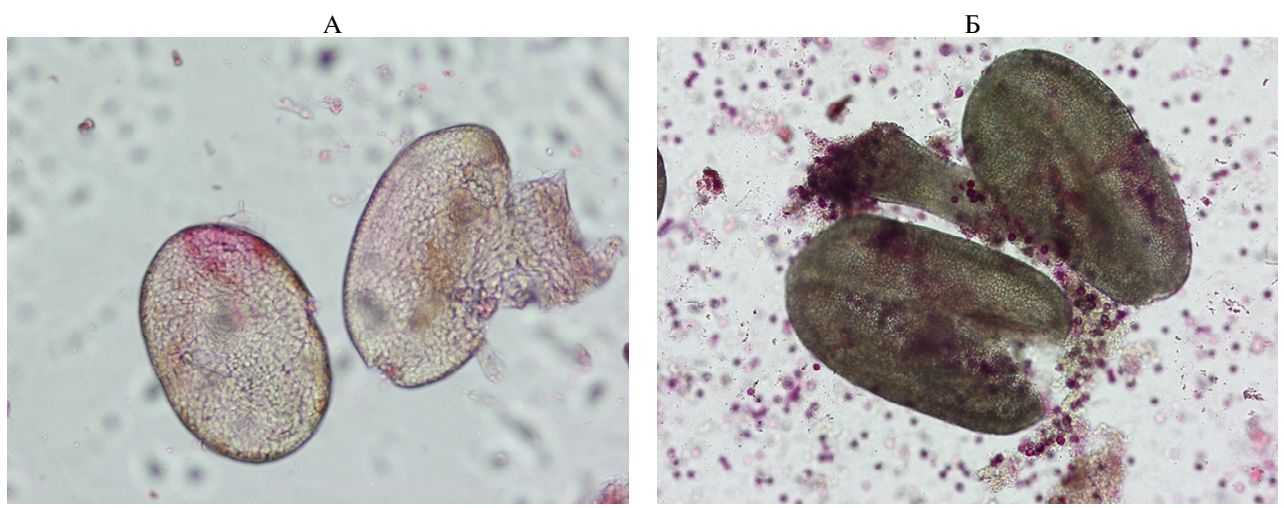

Рис. 2. Формирование археспориальной ткани в пыльниках на VI этапе органогенеза (А, 28 января 2010 года, благоприятные условия - температура выше $-24{ }^{\circ} \mathrm{C}$, влажность воздуха 65-75\%) и материнских клеток пыльцы на VII этапе органогенеза (Б, 15 марта 2019 года, температура не ниже 9-10 ${ }^{\circ} \mathrm{C}$ при влажности воздуха $60 \%$ ) у черешни Cerasus avium (L.) Moench copта Мак в Прикубанской зоне садоводства Краснодарского края (увеличение $\times 50-100$, Olympus BX41, «Olympus Corporation», Япония). Описание происхождения сорта см. в разделе «Методика».

A

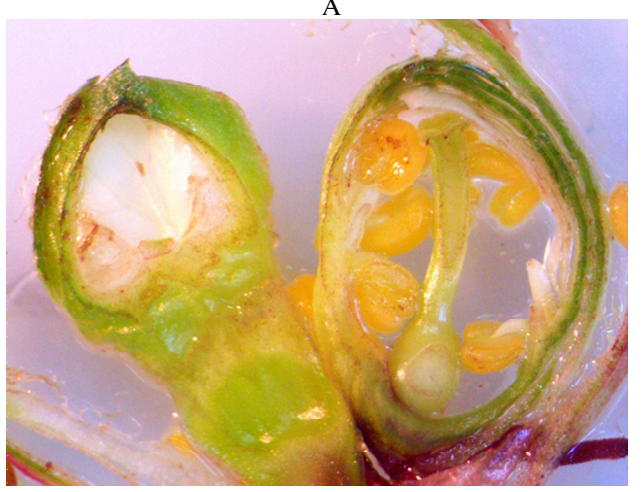

Б

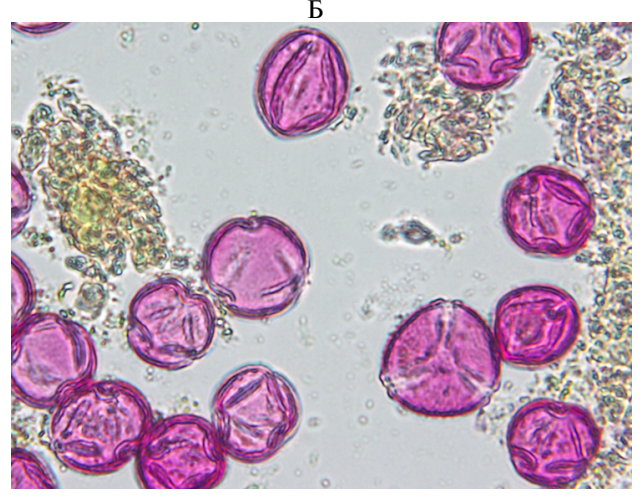

Рис. 3. Фенофазы «белый бутон» у вишни Cerasus vulgaris Mill. сорта Nefris на IX этапе органогенеза (А, общий вид, 5 апреля 2018 года, благоприятные условия) и «цветение» у вишни сор- 
та Игрушка на IX этапе органогенеза (Б, формирование одно-двуядерной пыльцы, 16 апреля 2010 года, благоприятные условия - температура в пределах $16-25^{\circ} \mathrm{C}$, влажность воздуха 55$58 \%$ в В Прикубанской зоне садоводства Краснодарского края (увеличение $\times 50-100$, Olympus BX41, «Olympus Corporation», Япония). Описание происхождения сортов см. в разделе «Методика».

Фенологические фазы «раздвижение чешуй» (VII этап органогенеза) (см. рис. 2) и «цветение-белый бутон» (IX этап) (рис. 3) мы рассматриваем как третий и четвертый критические этапы, определяющие продуктивность черешни и вишни. В условиях южного садоводства VII этап органогенеза приходятся на март-апрель, когда имеют место возвратные весенние заморозки (см. табл. 1). В начале вегетации, совпадающей с фенофазой «раздвижение чешуй», генеративные органы у черешни и вишни были особо чувствительны к температурным стрессам. По мнению некоторых исследователей, при снижении температуры воздуха до значений от $-3,0$ до $-6,0{ }^{\circ} \mathrm{C}$ на этом этапе сорта черешни и вишни практически полностью могут лишиться урожая $(11,17)$, что подтвердили и наши результаты. Так, возвратные заморозки до $-6,2{ }^{\circ} \mathrm{C}$, отмеченные 10 апреля 2009 года, привели к подмерзанию и значительным потерям элементов плодоношения. У сортов черешни местной селекции гибель плодовых почек составляла 80-85 \%, у интродуцированных - 90-95 \% при сниженном урожае в обеих генетических группах - 3,0-7,0 кг/дерево. У межвидовых гибридов гибель плодовых почек была 90-95 \%, при этом сформировался низкий урожай $-2,0-4,5$ кг/дерево. Европейские сорта типичной вишни показали более высокую устойчивость к весенним заморозкам, гибель плодовых почек у них составила 75-78 \%, что позволило сформировать урожай 7,08,0 кг/дерево.

Возвратные заморозки со снижением температуры до $-3,0{ }^{\circ} \mathrm{C}$ (и даже до $\left.-4,0{ }^{\circ} \mathrm{C}\right)$, отмечавшиеся 25 марта 2013 года, также привели к подмерзанию 40-50 \% плодовых почек. При этом у отечественных сортов Алая и Кавказская гибель генеративных органов составила 40 \% и сформировался урожай 18,0-20,0 кг/дерево, что дает основание говорить об их устойчивости к весенним заморозкам. У межвидовых гибридов подмерзание плодовых образований составило 30-40 \%, у сортов вишни обыкновенной - 15-25 \%, урожай соответственно 10,0 и 22,0 кг/ дер. Микроскопическое исследование плодовых почек черешни и вишни в период возвратных заморозков показало, что у пыльников сохранялась качественная, без видимых аномалий пыльца, но пестик повреждался, то есть был менее морозостойким, чем другие органы цветка, что согласуется с полученными ранее данными $(9,24)$. По результатам наших исследований, сорта вишни в сравнении с изученными сортами черешни обыкновенной характеризуются более высокой устойчивостью к низким отрицательным температурам в период покоя и в начале вегетации. При этом мы установили проявление сортовых особенностей, а также тесную корреляционную зависимость между критической температурой и редукцией генеративных органов $(r=+0,97, \mathrm{p}<0,001)$.

Наиболее уязвимыми для температурных стрессов оказались фенофазы «белый бутон» и «цветение» (IX этап органогенеза) (см. табл. 1, рис. 3), для которых, по мнению некоторых ученых, оптимален температурный режим в пределах $16,0-25,0{ }^{\circ} \mathrm{C}(17,28)$, что согласуется с полученными нами результатами. Мы установили, что при температурах воздуха выше $26,0{ }^{\circ} \mathrm{C}$ в период цветения изученных сортов черешни и виш- 
ни (I-II декады апреля) процесс старения цветка ускорялся в силу подсыхания пестика и семяпочки, что приводило к нарушению оплодотворения и существенной потере урожая.

Фенофаза «формирование завязи» (Х этап органогенеза) была менее других подвержена воздействию стрессов. На этом этапе (I-II декады мая) в условиях южного садоводства высока степень воздействия на растения аномально высоких температур, вызывавших осыпание $40 \%$ завязи у сортов черешни, $42 \%-$ у межвидовых гибридов и $46 \%-$ у сортов вишни обыкновенной (см. табл. 1).

С учетом того, что сорт служит основным элементом стабильного получения высоких урожаев у плодовых культур $(12,13)$, одним из этапов наших исследований была оценка продуктивности сортов вишни и черешни с целью выделения наиболее урожайных в условиях воздействия комплекса стрессов. При благоприятных условиях у сортов косточковых культур на одном дереве формируется значительное число вегетативных и плодовых почек, соотношение которых существенно различается (8), что было подтверждено и нашими результатами $(C v=20 \%)$. У черешни в зависимости от сорта число плодовых почек составляло в среднем от 68 шт. (сорт Кавказская) до 128 шт. (сорт Алая), вегетативных - от 26 шт. (сорт Дар изобилия) до 35 шт. (сорт Мелитопольская черная). Все сорта черешни по количеству формировавшихся плодовых почек достоверно превосходили контроль $\left(\mathrm{HCP}_{05}=3,1\right)$. У сортов вишни обыкновенной количество плодовых почек варьировало от 68 шт. (сорт Fanal) до 124 шт. (сорт Kelleris) с превышением контроля $\left(\mathrm{HCP}_{05}=3,5\right)$. Число вегетативных почек у сортов вишни варьировало умеренно $(C v=20 \%)-$ от 25 шт. (сорт Fanal) до 40 шт. (сорт Kelleris). У вишне-черешневых гибридов число плодовых почек составило 64 шт. у сорта Домбазия и 118 шт. у сорта Кирина, вегетативных - 24 шт. у сорта Игрушка и 37 шт. у сорта Шалунья (табл. 2). Как видно, число формирующихся плодовых почек было значительно больше, чем вегетативных, что свидетельствует о высоком потенциале продуктивности сортов черешни и вишни обыкновенной.

2. Основные элементы продуктивности у изученных сортов черешни Cerasus avium (L.) Moench и вишни обыкновенной Cerasus vulgaris Mill. разного эколого-географического происхождения (ОПХ «Центральное» СКФНЦСВВ, г. Краснодар, 2006-2018 годы)

\begin{tabular}{|c|c|c|c|c|c|c|}
\hline \multirow{3}{*}{ Сорт } & \multicolumn{5}{|c|}{ Биологический потенциал, шт/м ( $M \pm \mathrm{SD})$} & \multirow{3}{*}{$\begin{array}{l}\text { Коэффициент } \\
\text { плодоношения } \\
(\text { Кп), \% }\end{array}$} \\
\hline & \multicolumn{2}{|c|}{ почки } & \multirow{2}{*}{ цветок } & \multirow{2}{*}{ завязь } & \multirow{2}{*}{ плод } & \\
\hline & плодовые & ростовые & & & & \\
\hline \multirow{2}{*}{\multicolumn{7}{|c|}{$\begin{array}{c}\text { Ч е } \mathrm{p} \mathrm{e} \mathrm{ш} \mathrm{н} \mathrm{я} \mathrm{Cerasus} \mathrm{avium}(\mathrm{L} .) \text { Moench } \\
\text { Сорта черешни селекиии СКФНШСВВ }\end{array}$}} \\
\hline \multicolumn{4}{|c|}{ Сорта черешни селекции СКФНЦСВВ } & & & \\
\hline Кавказская (St) & $68 \pm 12$ & $30 \pm 6$ & $310 \pm 22$ & $226 \pm 7$ & $192 \pm 4$ & 62 \\
\hline Сашенька & $75 \pm 15$ & $31 \pm 10$ & $237 \pm 17$ & $134 \pm 5$ & $107 \pm 5$ & 45 \\
\hline Волшебница & $98 \pm 12$ & $29 \pm 5$ & $384 \pm 28$ & $222 \pm 10$ & $160 \pm 3$ & 42 \\
\hline Дар изобилия & $85 \pm 10$ & $26 \pm 8$ & $255 \pm 31$ & $159 \pm 4$ & $102 \pm 7$ & 40 \\
\hline Алая & $128 \pm 14$ & $33 \pm 5$ & $430 \pm 20$ & $266 \pm 5$ & $196 \pm 5$ & 46 \\
\hline Мак & $76 \pm 11$ & $32 \pm 7$ & $220 \pm 19$ & $129 \pm 6$ & $75 \pm 6$ & 35 \\
\hline \multicolumn{7}{|c|}{ Интродуцированные сорта черешни } \\
\hline Валерий Чкалов & $76 \pm 10$ & $28 \pm 11$ & $225 \pm 15$ & $182 \pm 8$ & $47 \pm 7$ & 21 \\
\hline $\begin{array}{l}\text { Мелитопольская } \\
\text { черная }\end{array}$ & $94+18$ & $35 \pm 6$ & 405 & $173 \pm 10$ & $98+3$ & 23 \\
\hline Полянка & $80 \pm 15$ & $29 \pm 15$ & $325 \pm 20$ & $186 \pm 9$ & $125 \pm 5$ & 35 \\
\hline $\mathrm{HCP}_{05}$ & 3,1 & 2,8 & 7,4 & 5,5 & 5,6 & 3,1 \\
\hline $\mathrm{SD}, \%$ & 17,0 & 2,7 & 81,2 & 44,9 & 51,1 & \\
\hline$M_{\text {cp. по черешне }}$ & 89,0 & 30,0 & 310,1 & 186,3 & 122,4 & \\
\hline$C v, \%$ & 20,0 & 8,9 & 26,2 & 24,1 & 41,6 & \\
\hline $\mathrm{Sx}, \%$ & 5,6 & 0,9 & 27,1 & 14,9 & 17,0 & \\
\hline
\end{tabular}




\begin{tabular}{|c|c|c|c|c|c|c|}
\hline \multicolumn{7}{|c|}{ Интродуцированные сорта вишни обыкновенной } \\
\hline Kelleris & $124 \pm 19$ & $40 \pm 9$ & $295 \pm 19$ & $192 \pm 7$ & $134 \pm 4$ & 45 \\
\hline Nefris & $103 \pm 16$ & $29 \pm 5$ & $322 \pm 25$ & $164 \pm 11$ & $120 \pm 2$ & 37 \\
\hline Fanal & $68 \pm 21$ & $25 \pm 12$ & $200 \pm 18$ & $94 \pm 4$ & $70 \pm 8$ & 35 \\
\hline Erdi Botermo & $88 \pm 18$ & $30 \pm 10$ & $228 \pm 16$ & $110 \pm 5$ & $87 \pm 5$ & 38 \\
\hline \multicolumn{7}{|c|}{ Вишне-черешневые гибриды } \\
\hline Домбазия & $64 \pm 15$ & $31 \pm 14$ & $160 \pm 22$ & $82 \pm 8$ & $52 \pm 9$ & 33 \\
\hline Дюк Ивановна & $95 \pm 10$ & $37 \pm 8$ & $250 \pm 20$ & $161 \pm 11$ & $110 \pm 4$ & 44 \\
\hline Дюк Ходоса & $88 \pm 19$ & $30 \pm 15$ & $198 \pm 18$ & $125 \pm 5$ & $90 \pm 8$ & 46 \\
\hline Встреча & $102 \pm 12$ & $33 \pm 11$ & $306 \pm 11$ & $173 \pm 8$ & $119 \pm 3$ & 39 \\
\hline Кирина (St) & $118 \pm 7$ & $36 \pm 9$ & $280 \pm 10$ & $168 \pm 10$ & $123 \pm 5$ & 44 \\
\hline Игрушка & $97 \pm 17$ & $24 \pm 17$ & $286 \pm 17$ & $130 \pm 7$ & $105 \pm 2$ & 37 \\
\hline Шалунья & $108 \pm 11$ & $37 \pm 13$ & $247 \pm 15$ & $153 \pm 4$ & $95 \pm 7$ & 38 \\
\hline $\mathrm{HCP}_{05}$ & 3,5 & 2,7 & 3,4 & 2,8 & 2,2 & \\
\hline $\mathrm{SD}, \%$ & 18,5 & 5,1 & 51,3 & 35,3 & 24,6 & \\
\hline$M_{\text {cp. по вишне }}$ & 95,9 & 32,0 & 252,0 & 141,1 & 100,5 & \\
\hline$C v, \%$ & 19,2 & 16,0 & 20,4 & 25,0 & 24,5 & \\
\hline Sx, \% & 5,6 & 1,5 & 15,5 & 10,6 & 7,5 & \\
\hline \multicolumn{7}{|c|}{$\begin{array}{l}\text { П р и м е ч а н и е. } \mathrm{St}-\text { сорт-стандарт; } C v-\text { коэффициент вариации, } \mathrm{SD}-\text { стандартное отклонение, } M- \\
\text { среднее арифметическое, } \mathrm{Sx}-\text { относительная стандартная ошибка выборочной средней (ошибка вы- } \\
\text { борки). Описание изученных сортов и гибридов см. в разделе «Методика». В среднем объем выборки в } \\
\text { год по черешне составлял } 2700-4500 \text { плодовых почек, } 4500-6800 \text { цветков; по вишне }-1500-3200 \text { плодо- } \\
\text { вых почек, } 2500-4700 \text { цветков. }\end{array}$} \\
\hline
\end{tabular}

Закладка большого числа плодовых почек рассматривается как важный адаптационный механизм, выработанный в процессе эволюции у плодовых растений и используемый в качестве «страхового фонда» в случае возможной редукции цветков, завязей и плодов после воздействия стрессовых факторов $(10,37)$. Один из значимых показателей потенциала продуктивности сорта - коэффициент плодоношения $(5,13)$. Анализ полученных нами данных показал, что потенциал по цветкам на 1 м плодовой древесины у сортов черешни варьировал значительно $(C v=26,2 \%)-$ от 220 (сорт Мак) до 430 (сорт Алая); у сортов вишни умеренно $(C v=20,4 \%)$ - от 160 (сорт Домбазия) до 322 (сорт Nefris) (см. табл. 2). По мнению некоторых ученых, естественные потери, или «очищение», на этапах образования завязи и плода достаточно высоки $(5,11)$. По нашим данным, с учетом редукции неопыленных или отставших в развитии цветков на IX этапе органогенеза у черешни формировалось 129 завязей у сорта Мак и $266-$ у сорта Алая, что превысило показатели контроля (сорт Кавказская), у которого в среднем отмечали 226 завязей $\left(\mathrm{HCP}_{05}=5,5\right)$. У сортов вишни формировалось меньшее (в сравнении с сортами черешни) и значительно варьировавшее ( $C v=25,0 \%)$ число завязей - от 94 шт. у сорта Fanal до 192 шт. у сорта Kelleris (см. табл. 2).

В среднем за годы исследований редукция на этапах образования завязи и плода у сортов черешни составила $40 \%$, у вишни - $46 \%$, у межвидовых гибридов - $42 \%$.

Конечный результат реализации потенциала продуктивности черешни и вишни оценивали в фенофазу созревания плодов (XI-XII этапы органогенеза). У сортов черешни в благоприятных условиях формировалось 75-196 плодов, у вишни обыкновенной - 70-134 плода, у вишнечерешневых гибридов - 52-123 плода на 1 м плодовой древесины.

На последних этапах развития редукция плодов существенно снижалась, что позволило рассчитать оптимальный коэффициент плодоношения. У сортов черешни он составил в среднем $43 \%$, у вишне-черешневых гибридов - $40 \%$, у сортов вишни обыкновенной - $38 \%$. Необходимо отметить, что сорта местной селекции отличались от ряда интродуциро- 
ванных более высоким коэффициентом плодоношения. Так, у отечественного сорта Кавказская он составил $62 \%$, Алая - 46 \%, Сашенька - 45 \%, Волшебница - 42 \%. Высокий коэффициент плодоношения сортов черешни соответствовал и более высокому урожаю, составившему в среднем 4550 кг/дерево, или 29,9-33,3 т/га, при схеме посадки $5 \times 3$ м (см. табл. 2, 3).

Анализ полученных результатов позволил выделить сорта вишни обыкновенной с высоким коэффициентом плодоношения Kelleris (45 \%) и Erdi Botermo (38 \%), вишне-черешневые гибриды Дюк Ходоса (46 \%), Кирина (44 \%) и Дюк Ивановна (44\%). У сортов вишни и вишне-черешневых гибридов также формировался достаточно высокий урожай - 30 40 кг/дерево, или 19,9-26,6 т/га, при схеме посадки 5×3 м (см. табл. 2, 3).

3. Урожайность изученных сортов черешни Cerasus avium (L.) Moench и вишни обыкновенной Cerasus vulgaris Mill. разного эколого-географического происхождения при действии стресс-факторов в условиях Прикубанской зоны садоводства Краснодарского края (схема посадки $5 \times 3$ м, ОПХ «Центральное» СКФНЦСВВ, г. Краснодар, 2006-2018 годы)

\begin{tabular}{|c|c|c|c|c|c|c|c|c|}
\hline \multirow{3}{*}{ Copt } & \multicolumn{8}{|c|}{ Продуктивность } \\
\hline & \multicolumn{2}{|c|}{$\begin{array}{l}2006 \text { год (январь, } \\
\left.-33,0{ }^{\circ} \mathrm{C}\right)\end{array}$} & \multicolumn{2}{|c|}{$\begin{array}{l}2009 \text { год (апрель, } \\
\left.-6,2^{\circ} \mathrm{C}\right)\end{array}$} & \multicolumn{2}{|c|}{$\begin{array}{l}2013 \text { год (март, от } \\
\left.-3,0 \text { до }-4,0^{\circ} \mathrm{C}\right)\end{array}$} & \multicolumn{2}{|c|}{2018 год (оптимум) } \\
\hline & $\mathrm{P}, \%$ & $\begin{array}{l}\text { Кг/дерево } \\
(M \pm \mathrm{SD})\end{array}$ & $\mathrm{P}, \%$ & $\begin{array}{l}\text { Кг/дерево } \\
(M \pm \mathrm{SD})\end{array}$ & $\mathrm{P}, \%$ & $\begin{array}{l}\text { Кг/дерево } \\
(M \pm \mathrm{SD})\end{array}$ & $\mathrm{P}, \%$ & $\begin{array}{l}\mathrm{Kг} / \text { дерево } \\
(M \pm \mathrm{SD})\end{array}$ \\
\hline \multicolumn{9}{|c|}{$\begin{array}{l}\text { Ч е р е ш н я Cerasus avium (L.) Moench } \\
\text { Cорта черешни селекции СКФНЦСВВ }\end{array}$} \\
\hline Кавказская (St) & 90 & $5,5 \pm 1,0$ & 80 & $7,0 \pm 2,0$ & 40 & $18,0 \pm 2,5$ & 0 & $35,0 \pm 5,0$ \\
\hline Алая & 90 & $5,0 \pm 2,0$ & 80 & $7,0 \pm 3,0$ & 40 & $20,0 \pm 4,0$ & 0 & $47,0 \pm 5,0$ \\
\hline Дар изобилия & 92 & $4,5 \pm 1,5$ & 82 & $5,0 \pm 2,5$ & 45 & $17,0 \pm 3,5$ & 0 & $40,0 \pm 3,5$ \\
\hline Волшебница & 90 & $5,0 \pm 2,5$ & 85 & $6,0 \pm 1,5$ & 45 & $17,0 \pm 3,0$ & 0 & $35,0 \pm 4,0$ \\
\hline Мак & 94 & $3,0 \pm 2,5$ & 80 & $7,0 \pm 1,0$ & 50 & $15,0 \pm 4,5$ & 0 & $45,0 \pm 3,5$ \\
\hline Сашенька & 95 & $1,0 \pm 0,5$ & 85 & $5,5 \pm 2,5$ & 50 & $15,0 \pm 3,0$ & 0 & $30,0 \pm 4,5$ \\
\hline \multicolumn{9}{|c|}{ Интродуцированные сорта черешни } \\
\hline Валерий Чкалов & 100 & $1,0 \pm 0,5$ & 95 & $0,0 \pm 0,0$ & 52 & $12,5 \pm 4,0$ & 0 & $15,0 \pm 5,0$ \\
\hline $\begin{array}{l}\text { Мелитопольская } \\
\text { черная }\end{array}$ & 96 & $1,0 \pm 0,5$ & 90 & $3,0 \pm 1,0$ & 55 & $10,0 \pm 2,5$ & 0 & $25,0 \pm 3,0$ \\
\hline Полянка & 100 & $0,0 \pm 0,0$ & 95 & $1,0 \pm 0,5$ & 55 & $10,0 \pm 4,0$ & 0 & $30,0 \pm 2,5$ \\
\hline $\mathrm{HCP}_{05}$ & 1,35 & 0,99 & 1,69 & 1,12 & 1,70 & 1,20 & 0 & 2,10 \\
\hline $\mathrm{SD}, \%$ & 4,0 & 2,2 & 6,2 & 2,7 & 5,8 & 3,5 & 0 & 10,0 \\
\hline$M_{\text {cp. по черешне }}$ & 94,1 & 2,8 & 85,7 & 4,6 & 48,0 & 14,9 & 0 & 33,6 \\
\hline$C v, \%$ & 4,3 & 75,8 & 7,2 & 58,0 & 12,0 & 23,0 & 0 & 29,0 \\
\hline $\mathrm{Sx}, \%$ & 1,3 & 30,7 & 2,1 & 0,9 & 1,9 & 1,2 & 0 & 3,3 \\
\hline \multicolumn{9}{|c|}{$\begin{array}{l}\text { В и ш н я Cerasus vulgaris Mill. } \\
\text { одуцированные сорта вишни обыкновенной }\end{array}$} \\
\hline Kelleris & 85 & $8,0 \pm 2,0$ & 75 & $8,0 \pm 1,5$ & 20 & $22,0 \pm 4,5$ & 0 & $30+45$ \\
\hline Nefris & 88 & $7,0 \pm 1,5$ & 76 & $7,5 \pm 2,5$ & 15 & $20,0 \pm 3,0$ & 0 & $25 \pm 3,0$ \\
\hline Fanal & 85 & $7,5 \pm 2,5$ & 75 & $7,5 \pm 1,5$ & 20 & $18,0 \pm 3,5$ & 0 & $20 \pm 3,5$ \\
\hline Erdi Botermo & 90 & $5,0 \pm 3,0$ & 78 & $7,0 \pm 3,0$ & 25 & $15,0 \pm 2,5$ & 0 & $25 \pm 2,0$ \\
\hline \multicolumn{9}{|c|}{ Вишне-черешневые гибриды } \\
\hline Домбазия & 90 & $6,0 \pm 2,5$ & 90 & $4,0 \pm 3,5$ & 40 & $10,0 \pm 4,0$ & 0 & $28 \pm 1,5$ \\
\hline Дюк Ивановна & 95 & $4,0 \pm 3,0$ & 93 & $3,0 \pm 2,5$ & 40 & $10,5 \pm 3,0$ & 0 & $30 \pm 1,0$ \\
\hline Дюк Ходоса & 90 & $5,0 \pm 2,5$ & 90 & $4,5 \pm 1,5$ & 30 & $15,0 \pm 2,0$ & 0 & $35 \pm 2,0$ \\
\hline Встреча & 90 & $6,0 \pm 2,0$ & 92 & $3,0 \pm 2,0$ & 35 & $13,0 \pm 5,0$ & 0 & $28 \pm 1,5$ \\
\hline Кирина (St) & 91 & $4,0 \pm 1,5$ & 95 & $2,0 \pm 1,5$ & 30 & $15,0 \pm 3,5$ & 0 & $35 \pm 1,0$ \\
\hline Игрушка & 95 & $4,0 \pm 2,5$ & 90 & $4,0 \pm 1,0$ & 35 & $15,0 \pm 2,0$ & 0 & $25 \pm 2,5$ \\
\hline Шалунья & 95 & $4,0 \pm 3,0$ & 95 & $2,0 \pm 0,5$ & 35 & $15,5 \pm 2,5$ & 0 & $28 \pm 2,0$ \\
\hline $\mathrm{HCP}_{05}$ & 1,1 & 0,8 & 2,0 & 0,9 & 2,1 & 1,1 & 0 & 1,6 \\
\hline $\mathrm{SD}, \%$ & 3,6 & 1,5 & 8,4 & 2,3 & 8,5 & 3,6 & 0 & 4,4 \\
\hline$M$ ср. по вишне & 90,4 & 5,5 & 86,3 & 4,8 & 29,5 & 15,4 & 0 & 28,1 \\
\hline$C v, \%$ & 4,0 & 27,0 & 9,7 & 48,0 & 28,8 & 23,3 & 0 & 15,6 \\
\hline Sx, \% & 1,1 & 0,46 & 2,5 & 0,7 & 2,6 & 1,1 & 0 & 1,3 \\
\hline $\begin{array}{l}\text { П р и м е ч ан и е. } \\
\text { среднее арифмети } \\
\text { борки). Р - реду } \\
\text { «Методика». В ср } \\
\text { плодовых почек. }\end{array}$ & $\begin{array}{l}\text { t }- \text { со } \\
\text { еское, } \\
\text { дия (гу } \\
\text { нем о }\end{array}$ & $\begin{array}{r}\text { стандарт; } \\
- \text { относ } \\
\text { ль) плодо } \\
\text { м выборк }\end{array}$ & $\begin{array}{l}v-\text { коэ } \\
\text { ельная } \\
\text { IX поче } \\
\text { в стрес }\end{array}$ & $\begin{array}{l}\text { ициент вар } \\
\text { 1ндартная о } \\
\text { Описание и } \\
\text { ые годы по }\end{array}$ & $\begin{array}{l}\text { иации, S } \\
\text { шибка } \\
\text { зученны } \\
\text { черешн }\end{array}$ & $\begin{array}{l}\text { стандартн } \\
\text { рочной ср } \\
\text { ртов и гиб } \\
\text { по вишне }\end{array}$ & $\begin{array}{l}\text { ное отк. } \\
\text { редней } \\
\text { бридов } \\
\text { состав }\end{array}$ & $\begin{array}{l}\text { нение, } M- \\
\text { ошибка вы- } \\
\text { м. в разделе } \\
\text { л } 2500-2700\end{array}$ \\
\hline
\end{tabular}


Необходимо отметить, что формирование высокого урожая у сортов черешни и вишни возможно при условии минимального воздействия стрессовых факторов на всех этапах формирования элементов продуктивности. В таблице 3 представлены результаты, характеризующие реализацию продуктивного потенциала у сортов черешни и вишни обыкновенной в экстремальные годы. Так, в 2006 году в период покоя температура опускалась до $-33,0{ }^{\circ} \mathrm{C}$, в результате чего редукция элементов продуктивности сортов косточковых достигала 90-100\%. На этом фоне выделялись сорта черешни Алая и Волшебница, у которых сформировался урожай порядка 5,0 кг/дерево. У вишни и вишне-черешневых гибридов редукция элементов продуктивности была ниже, чем у сортов черешни, и составила 8595 \%. Так, сорта вишни Встреча, Домбазия, Дюк Ходоса, Kelleris и Fanal по сформировавшемуся урожаю достоверно $\left(\mathrm{HCP}_{05}=0,8\right)$ превосходили контрольный сорт Кирина. В 2009 году из-за возвратных заморозков $\left(-6,2{ }^{\circ} \mathrm{C}\right)$ в период цветения редукция плодовых элементов косточковых культур была высокой: у изученных сортов черешни она составила 85$95 \%$, при этом варьирование по сортам оказалось низким $(C v=7,2 \%)$. У вишни и вишне-черешневых гибридов происходила гибель 75-95 \% плодовых почек, варьирование показателей по сортам было незначительным $(C v=9,7 \%)$. В 2013 году понижение температуры до $-3,0$ и $-4,0{ }^{\circ} \mathrm{C}$ пришлось на фенофазу «белый бутон». В этих условиях редукция генеративных органов у разных сортов черешни составила 40-55 \%, у сортов вишни и вишне-черешневых гибридов - 15-40 \% (см. табл. 3).

Сравнительный анализ урожайности сортов черешни и вишни показал, что эти косточковые культуры обладают высоким продуктивным потенциалом, который реализуется максимально в оптимальных погодных условиях. Так, у сортов черешни в благоприятном 2018 году в среднем сформировался урожай 33,6 кг/дерево. По урожайности выделялись сорта черешни Дар изобилия (40,0 кг/дерево), Мак (45,0кг/дерево) и Алая (47,0 кг/дерево), достоверно превосходившие контрольный сорт. У сортов вишни в 2018 году также отмечали высокий средний урожай - 28,1 кг/дерево. По урожайности выделялись сорта Дюк Ивановна (30 кг/дерево) и Kelleris (30 кг/дерево).

Итак, в условиях Краснодарского края у сортов и гибридов черешни и вишни нами выделены пять критических этапов органогенеза, или фенологических фаз, когда растения наиболее чувствительны к воздействию температурных стрессов и с высокой долей вероятности происходит редукция элементов продуктивности. Эти этапы - закладка генеративных органов, образование археспория в пыльниках (период покоя), формирование материнских клеток пыльцы (раздвижение чешуй), стадия однодвухъядерной пыльцы («белый бутон»-цветение) и макроспорогенез (формирование завязи). Уточнены средние сроки прохождения критических этапов в условиях Прикубанской зоны садоводства - декабрьянварь, II-III декады марта, I-II декады апреля, I-II декады мая, I-II декады июля, что позволяет разработать рекомендации для проведения превентивных мероприятий по стабилизации урожая. Установлено, что степень реализации продуктивного потенциала черешни и вишни обыкновенной находится в тесной зависимости от типа температурных стрессов и количества элементов плодоношения, сохранившихся после редукции на всех уязвимых этапах органогенеза $(r=+0,97, \mathrm{p}<0,001)$. Выделены устойчивые к температурным стрессам и наиболее продуктивные в условиях южного садоводства отечественные сорта черешни Кавказская (коэффици- 
ент плодоношения и урожайность соответственно $62 \%$ и 31,3 т/га,), Сашенька (45 \% и 26,6 т/га), Волшебница (42\% и 23,3 т/га), Алая (46 \% и 30,0 т/га), сорт вишни обыкновенной Kelleris (45\% и 20,0 т/га), а также вишне-черешневые гибриды Дюк Ходоса (46 \% и 23,3 т/га), Кирина (44 \% и 23,3 т/га) и Дюк Ивановна (44\% и 20,0 т/га). Они рекомендуются для оптимизации и расширения сортимента косточковых культур Краснодарского края, а также включения в селекционный процесс в качестве источников генов высокой продуктивности и адаптивности к комплексу температурных стрессов.

\author{
ФГБНУ Северо-Кавказский ФНЦ садоводства, \\ виноградарства, виноделия, \\ 350901 Россия, Краснодарский край, г. Краснодар, \\ ул. им. 40-летия Победы, 39 , \\ e-mail: zaremuk_rimma@mail.ru $\bowtie$, skzniisiv2015@mail.ru, \\ tatjanakopnina@rambler.ru
}

Поступила в редакцию

19 октября 2019 года

Sel'skokhozyaistvennaya biologiya [Agricultural Biology], 2020, V. 55, № 3, pp. 573-587

\title{
PRODUCTIVITY POTENTIAL OF DRUP FRUIT VARIETIES - BIOMORPHOLOGICAL FEATURES OF FORMATION AND REALIZATION UNDER THE CLIMATIC CONDITIONS OF SOUTH RUSSIA
}

\author{
R.Sh. Zaremuk, Yu.A. Dolya, T.A. Kopnina
}

\begin{abstract}
North-Caucasian Federal Scientific Center of Horticulture, Viticulture, Winemaking, 39, ul. im. 40-letiya Pobedy, Krasnodar,350901 Russia, e-mail zaremuk_rimma@mail.ru ( $₫$ corresponding author), skzniisiv2015@mail.ru, tatjanakopnina@rambler.ru

Acknowledgements:

The research was done using the equipment of the Center for Collective Use (CKP) "Genetic Collection of Fruit Crops" of the North-Caucasian Federal Scientific Center of Horticulture, Viticulture, Winemaking (Krasnodar). ORCID:

Zaremuk R.Sh. orcid.org/0000-0003-0298-0914

Kopnina T.A. orcid.org/0000-0003-3456-1597
\end{abstract}

Dolya Yu.A. orcid.org/0000-0002-1623-1511

The authors declare no conflict of interests

Received October 19, 2019

doi: $10.15389 /$ agrobiology.2020.3.573eng

\section{Abstract}

Productivity, the main characteristic of a variety of fruit crops, which is due to a set of elements, determines the resistance of a crop to environmental stress factors and its suitability for industrial growing conditions. The impact of climatic stresses annually results in only $30-40 \%$ realization of productivity potential of fruit plants. In fruit plants, including sweet and ordinary cherries, fruit-bud differentiation takes a long time. In the conditions of the southern Russia (Prikubanskaya gardening zone of the Krasnodar Territory), it begins in July of the current year and ends in AprilMay of the next year. The climate in the Krasnodar Territory is quite mild, generally favorable for the cultivation of sweet and ordinary cherries. Nevertheless, even in the south of Russia, there is a high risk of annual abiotic stresses, negatively affecting fruit plants and impeding realization of their productivity potential. In the present work, a comprehensive biomorphological study was first undertaken to assess the regional productivity potential of sweet and ordinary cherries of various ecological and geographical origins. Our research aimed to establish the regional patterns of productivity element formation during morpho- and organogenesis in Prunus L. species and hybrids, to identify the most vulnerable stages in plant annual development cycles, and to distinguish the varieties with high and sustainable yielding under risky weather conditions. Three introduced Cerasus avium (L.) Moench varieties of different ecogeographic origins (Valerii Chkalov, Melitopolskaya Chernaya, and Polyanka), six domestic C. avium varieties (Kavkazskaya, Sashen'ka, Volshebnitsa, Dar izobiliya, Alaya, and Mak), four introduced C. vulgaris Mill. varieties (Kelleris, Nefris, Fanal, and Erdi Botermo), and seven interspecific hybrids $C$. vulgaris $\times$ C. avium (Kirina, Dombaziya, Duk Ivanovna, Duk Khodosa, Igrushka, and Shalun'ya) were studied during 2006-2019, Experimental Production Center of the North-Caucasian Federal Scientific Center of Horticulture, Viticulture, Winemaking, Krasnodar; $6 \times 4,7 \times 3$, and $5 \times 3 \mathrm{~m}$ plant spacing). Cerasus mahaleb (L.) Mill. And Cerasus avium L. plants were rootstock plants, all experiments were arranged in three replications. Phenology of all stages and sub-stages of the annual (vegetative and generative) plant growth was described as per BBCH system (Biologische Bundesanstalt, Bundessortenamt and Chemische Industrie, Germany). Morphogenesis of yield components was investigated in 15 generative buds 2 
times in December and February, weekly in March-April, and weekly in July-November by light microscopy (Olympus BX41, Olympus Corporation, Japan). In spring, flowers, ovaries, and fruits were gradually counted on third-order skeletal branches, and the degree of their reduction were calculated to estimate biological productivity. The number of fruit buds and growth buds was estimated 2 times a week in August and September. To assess the winter hardiness, 90 vegetative buds and 180 fruit buds from different sides of the lower and upper branches of 3 trees of the same variety were collected in 3 replicates. It was found that the reduction of productivity elements in the stressful conditions of southern gardening occurs annually at the same (critical) stages of development of fruit plants. These stages are i) reproductive organ initiation; ii) archesporium formation in anthers; iii) pollen mother cells, iv) mono- and binuclear pollen grains, and v) macrosporogenesis. The critical periods of yield formation in the conditions of the Krasnodar Territory are II-III decades of March, and I-II decades of April, May and July, when special agrotechnology should be applied to reduce the impact of stress and to increase yields. A direct correlation was revealed between temperature and air humidity during each critical period, the fruiting coefficient and the final yield $(r=+0,97, \mathrm{p}<0,001)$. In our tests, the following samples are characterized by high fruiting rates and sustainable yields: domestic cherry varieties Kavkazskaya (62 \% and 31.3 t/ha, respectively), Alaya (46\% and 30.0 t/ha), Sashen'ka (45\% and $26.6 \mathrm{t} / \mathrm{ha}$ ), and Volshebnitsa (42\% and $23.3 \mathrm{t} / \mathrm{ha}$ ), interspecific hybrids Duk Khodosa (46\% and $23.3 \mathrm{t} / \mathrm{ha}$ ), Kirina (44\% and $23.3 \mathrm{t} / \mathrm{ha}$ ), and Duk Ivanovna (44\% and $20.0 \mathrm{t} / \mathrm{ha})$, and an ordinary cherry variety Kelleris (45\% and $20.0 \mathrm{t} / \mathrm{ha}$ ). These varieties and hybrids can be cultivated in commercial orchards and used as genetic donors in breeding for sustainable productivity.

Keywords: drup fruit, sweet cherry, ordinary cherry, varieties, abiotic factors, adaptive potential, biological productivity, generative development, organogenesis, yielding.

\section{REFEREN CES}

1. Bondarenko L.V., Maslova O.V., Belkina A. V., Sukhareva K.V. Vestnik Rossiiskogo ekonomicheskogo universiteta im. G.V. Plekhanova, 2018, 2(98): 84-93 (doi: 10.21686/2413-2829-2018-284-93) (in Russ.).

2. Campoy J., Ruiz D., Egea J. Dormancy in temperate fruit trees in a global warming context: a review. Scientia Horticulturae, 2011, 130(2): 357-372 (doi: 10.1016/j.scienta.2011.07.011).

3. Luedeling E. Climate change impacts on winter chill for temperate fruit and nut production: a review. Scientia Horticulturae, 2012, 144: 218-229 (doi: 10.1016/j.scienta.2012.07.011).

4. Else M., Atkinson C. Climate change impacts on UK top and soft fruit production Outlook on Agriculture, 2010, 39: 257-262 (doi: 10.5367/oa.2010.0014).

5. Alekhina E.M., Dolya Yu.A. Plodovodstvo $i$ vinogradarstvo Yuga Rossii, 2013, 24(06): 10-17 (in Russ.).

6. Dolya Yu.A. Formirovanie produktivnosti sortov chereshni v usloviyakh Severnogo Kavkaza. Kandidatskaya dissertatsiya [The formation of sweet cherry productivity in the North Caucasus. PhD Thesis]. Krasnodar, 2011 (in Russ.).

7. Chumakov S.S. Vozmozhnosti realizatsii biologicheskogo potentsiala plodovykh rastenii v raznovozrastnykh nasazhdeniyakh yuga Rossii [Possibilities for realizing the biological potential of fruiting plants in different-aged stands of Southern Russia]. Krasnodar, 2011 (in Russ.).

8. Eremina O.V. V sbornike: Metody i reglamenty optimizatsii strukturnykh elementov agrotsenozov $i$ upravleniya realizatsiei produktsionnogo potentsiala rastenii [In: Methods and regulations to optimize structural elements of agrocenoses and to manage realization of plants production potential]. Krasnodar, 2009: 185-189 (in Russ.).

9. Ozherel'eva Z.E., Gulyaeva A.A. Sovremennoe sadovodstvo, 2015, 3(15): 45-51 (in Russ.).

10. Buntsevich L.L. Morfofiziologicheskie osobennosti formirovaniya urozhainosti yabloni domashnei (Malus domestica Borkh.): monografiya [Morphophysiological features of domestic apple try (Malus domestica Borkh.) yield formation: a monograph]. Krasnodar, 2012 (in Russ.).

11. Zhuchenko A.A. Adaptivnoe rastenievodstvo: ekologo-geneticheskie osnovy [Adaptive crop production: ecological and genetic aspects]. Kishinev, 1990 (in Russ.).

12. Doroshenko T.N., Klad' A.A., Gegechkori B.S. Opredelenie produktivnosti plodovykh rastenii $i$ priemy ee regulirovaniya [Determination of fruit plant productivity and methods of its regulation]. Krasnodar, 1999 (in Russ.).

13. Dragavtsev V.A., Dragavtseva I.A., Mozhar N.V., Morenets A.S. Trudy Kubanskogo gosudarstvennogo agrarnogo universiteta, 2018, 72: 142-148 (doi: 10.21515/1999-1703-72-142-148) (in Russ.).

14. Spitsyn I.P. Tsitoembriologicheskie, geneticheskie $i$ ekologicheskie aspekty produktivnosti vishni. Avtoreferat doktorskoi dissertatsii [Cytoembryological, genetic and environmental aspects of cherry productivity. DSc Thesis]. Michurinsk, 2003 (in Russ.).

15. Taranov A.A. Plodovodstvo, 2005, 17(1): 63-67 (in Russ.).

16. Buntsevich L.L., Kostyuk M.A., Paletskaya E.N. Plodovodstvo i yagodovodstvo Rossii, 2013, 31(1): 55-61 (in Russ.).

17. Egorov E.A., Il'ina I.A., Prichko T.G., Dragavtseva I.A., Popova V.P., Alekhina E.M., Alferov V.A., Artyukh S.N., Khvostova I.V., Yakuba G.V., Cherkezova S.R., Podgornaya M.E., 
Smolyakova V.M., Efimova I.L., Ul'yanovskaya E.V., Shafrostova N.K., Zaremuk R.Sh., Sergeev Yu.I., Lugovskoi A.P., Teren'ko G.N., Kuznetsova A.P., Bogatyreva S.V., Mozhar N.V., Govorushchenko S.V., Tyshchenko E.L., Shadrina Zh.A. Adaptivnyi potentsial sadovykh kul'tur yuga Rossii $v$ usloviyakh stressovykh temperatur zimnego perioda (metodicheskie rekomendatsii) [Adaptive potential of garden crops in Southern Russia under stressful temperatures of the winter period (methodical recommendations)]. Krasnodar, 2006 (in Russ.).

18. Salazar-Gutiérrez M.R., Chaves B., Anothai J., Whiting M., Hoogenboom G. Variation in cold hardiness of sweet cherry flower buds through different phenological stages. Scientia Horticulturae, 2014, 172: 161-167 (doi: 10.1016/j.scienta.2014.04.002).

19. Hedhly A. Hormaza J.I., Herrero M. Warm temperatures at bloom reduce fruit set in sweet cherry. Journal of Applied Botany and Food Quality, 2007, 81(2): 158-164.

20. Zhang L., Ampatzidis Y., Whiting M.D. Sweet cherry floral organ size varies with genotype and temperature. Scientia Horticulturae, 2015, 182: 156-164 (doi: 10.1016/j.scienta.2014.09.051)

21. Woznicki T.L., Heide O.M., Sønsteby A., Måge F., Remberg S.F. Climate warming enhances flower formation, earliness of blooming and fruit size in plum (Prunus domestica L.) in the cool Nordic environment. Scientia Horticulturae, 2019, 257: 108750 (doi: 10.1016/j.scienta.2019.108750).

22. Rodrigo J., Herrero M. Effects of pre-blossom temperatures on flower development and fruit set in apricot. Scientia Horticulturae, 2002, 92(2): 125-135 (doi: 10.1016/S0304-4238(01)00289-8).

23. Götz K.-P., Chmielewski F.-M., Homann T., Huschek G., Matzneller P., Rawel H.M. Seasonal changes of physiological parameters in sweet cherry (Prunus avium L.) buds. Scientia Horticulturae, 2014, 172: 183-190 (doi: 10.1016/j.scienta.2014.04.012).

24. Vitkovskii V.L. Morfogenez plodovykh rastenii [Fruit plant morphogenesis]. Leningrad, 1984 (in Russ.).

25. Zhang L., Ferguson L., Whiting M.D. Temperature effects on pistil viability and fruit set in sweet cherry. Scientia Horticulturae, 2018, 241: 8-17 (doi: 10.1016/j.scienta.2018.06.039).

26. Kolomiets I.A. Preodolenie periodichnosti plodonosheniya yabloni [Overcoming the periodicity of fruiting apple trees]. Kiev, 1961 (in Russ.).

27. Sergeeva N.N., Buntsevich L.L. Morphogenetic features of development and the feed regime of an apple-tree in the conditions of south of Russia. Sel'skokhozyaistvennaya biologiya [Agricultural Biology], 2010, 5: 92-97 (in Russ.).

28. Hedhly A., Hormaza J.I., Herrero M. Effect of temperature on Pollen Tube Kinetics and Dynamics in sweet cherry, Prunus avium (Rosaceae). American Journal of Botany, 2004, 91(4): 558564 (doi: 10.3732/ajb.91.4.558).

29. Dragavtseva I.A. Razvitie tsvetkovykh pochek alychi $v$ svyazi s zimostoikost'yu ee sortov v usloviyakh Kryma. Avtoreferat kandidatskoi dissertatsii [Development of cherry plum flower buds in connection with the winter hardiness of varieties in Crimea. PhD Thesis]. Odessa, 1966 (in Russ.).

30. Sanzol J., Herrero M. The "effective pollination period" in fruit trees. Scientia Horticulturae, 2001, 90(1-2): 1-17 (doi: 10.1016/S0304-4238(00)00252-1).

31. Nen'ko N.I., Kiseleva G.K. V knige: Sovremennye metodologiya, instrumentarii otsenki $i$ otbora selektsionnogo materiala sadovykh kul'tur i vinograda [In: Modern methodology, tools for assessing and selecting breeding material for garden crops and grapes]. Krasnodar, 2017: 66-78 (in Russ.).

32. Koutinas N., Pepelyankov G., Lichev V. Flower induction and flower bud development in apple and sweet cherry. Biotechnology and Biotechnological Equipment, 2010, 24(1): 1549-1558 (doi: 10.2478/V10133-010-0003-9).

33. Rabadanova K.K., Tyutereva E.V., Matskevich V.S., Deminchik V.V., Voitsekhovskaya O.V. Cellular and molecular mechanisms controlling autophagy: a perspective to improve plant stress resistance and crop productivity (review). Sel'skokhozyaistvennaya biologiya [Agricultural Biology], 2018, 53(5): 881-896 (doi: 10.15389/agrobiology.2018.5.881eng).

34. Fadón E., Herrero M., Rodrigo J. Flower development in sweet cherry framed in the BBCH scale. Scientia Horticulturae, 2015, 192: 141-147 (doi: 10.1016/j.scienta.2015.05.027).

35. Dzhigadlo E.N., Kolesnikova A.F., Eremin G.V., Morozova T.V., Kan'shina M.V. V knige: Programma i metodika sortoizucheniya plodovykh, yagodnykh $i$ orekhoplodnykh kultur /Pod redaktsiei E.N Sedova, T.P. Ogol'tsovoi [In: The program and methodology to study fruit, berry and nutbearing crop varieties. E.N Sedov, T.P. Ogol'tsova (eds.)]. Orel, 1999: 300-350 (in Russ.).

36. Dzhigadlo E.N., Shchekotova L.A., Turovtsev N.I., Morozova T.V., Eremin G.V. V knige: Programma $i$ metodika selektsii plodovykh, yagodnykh $i$ orekhoplodnykh kul'tur /Pod redaktsiei E.N. Sedova [The program and method for fruit, berry and nut-bearing crop breeding. E.N. Sedov (ed.)]. Orel, 1995: 234-313 (in Russ.).

37. Isaeva I.S. Morfofiziologiya plodovykh rastenii. Kurs lektsii /Pod redaktsiei F.M. Kuperman [Morphophysiology of fruit plants. Lecture course. F.M. Kuperman (ed.)]. Moscow, 1974 (in Russ.).

38. Kiseleva G.K. V knige: Sovremennye metodologiya, instrumentarii otsenki i otbora selektsionnogo materiala sadovykh kultur $i$ vinograda [Modern methodology, tools for assessing and selecting breeding material for garden crops and grapes]. Krasnodar, 2017: 51-60 (in Russ.). 